\title{
Benign papillary cystadenofibroma of fallopian tube presenting as posterior fornix cyst: case report
}

\author{
Gude Prajakta Narayanrao $^{1 *}$, P. V. Srinivasan ${ }^{2}$, R. Kala ${ }^{1}$
}

\begin{abstract}
${ }^{1}$ Department of Obstetrics and Gynaecology, ${ }^{2}$ Department of Urology, District Government Headquarters Hospital, Cuddalore, Tamilnadu, India
\end{abstract}

Received: 08 October 2020

Revised: 14 November 2020

Accepted: 01 December 2020

\section{*Correspondence:}

Dr. Gude Prajakta Narayanrao, E-mail: drprajaktag@gmail.com

Copyright: (c) the author(s), publisher and licensee Medip Academy. This is an open-access article distributed under the terms of the Creative Commons Attribution Non-Commercial License, which permits unrestricted non-commercial use, distribution, and reproduction in any medium, provided the original work is properly cited.

\begin{abstract}
Benign papillary cystadenofibroma of fallopian tube is very rare tumor of female genital tract. Usually asymptomatic and incidental finding. Worldwide literature only 18 cases were found. On account of its rarity and best of our knowledge, is the first case of benign papillary cystadenofiboma presented as posterior fornix cyst, so we are presenting this case. We report a rare case of benign papillary cystadenofibroma of fallopian tube in a 30-years old female P3L3 presenting with abdominal pain. On examination abdomen was soft, per vaginally mobile non-tender cystic mass of $5 \times 4 \mathrm{~cm}$ was noted. Laparotomy was planned. Intraoperatively $5 \times 4 \mathrm{~cm}$ cyst arising from serosal surface of left fallopian tube near fimbrial end noted with bilateral ovaries normal. Left fimbrial cystectomy with salpingectomy was done with sparing both ovaries. Histopathology suggestive of benign papillary cystadenofibroma of fallopian tube. Patient had uneventful recovery in follow up period. Benign papillary cystadenofibroma of fallopian tube is rare tumor found incidentally. Tumor seems to have benign course only cystectomy is required for treatment.
\end{abstract}

Keywords: Fallopian tube, Benign papillary serous cystadenofibroma, Posterior fornix cyst, Benign, tumor

\section{INTRODUCTION}

Fallopian tubes tumors are rare in general and are the rarest tumors of female genital tract. Usually asymptomatic and incidental finding. Worldwide literature only 18 cases has been found. ${ }^{1}$ World Health Organization (WHO) classified tumors as- papillomas, cystadenoma, adenofibroma, cystadenofibroma (CAF), metaplastic papillary tumors and endometrioid polyps belong to group of benign tumors. $^{2}$ Serous papillary cystadenofibroma (SPCAF) is ususally located on fimbrial end of the tube and it is considered that it has "Müllerian" origin. Preoperative diagnosis is rare. It may appear macroscopically and ultrasonographically malignant. However, malignant potential is very rare. Usually occurs in younger women hence decision for radical surgery should be reconsidered.

\section{CASE REPORT}

30 years old P3L3, tubectomised patient was came to outpatient department (OPD) with case of pain in abdomen since 1 month, localised on left lower side of abdomen, dull aching, on and off, relieved by its own and not associated with nausea, vomiting, flatulence. No history of dyspareunia. Menstrual history is neat regular, no complaints. Obstetric history P3L3 with first birth by caesarean section and rest all vaginal deliveries. Last childbirth was male child 3 year. Sterilization done 3 years back. No bladder/bowel complaints. Past medical or surgical history was insignificant.

On clinical examination vitals were sable. Abdomen was soft, nontender and no mass was palpable. Transverse scar 
of caesarean section was seen. On per speculum examination fullness was seen in upper $1 / 3$ rd of posterior vaginal wall with absent cough impulse.

There was no bleeding or discharge. Per vaginal examination cervix was pointing downwards and uterus was ante verted, normal size. In posterior fornix $5 \times 4 \mathrm{~cm}$ cystic mass with smooth surface, mobile and nontender was felt. Other fornices were free and nontender. Per rectal examination same cystic mass was felt.

Differential diagnosis for posterior vaginal wall cyst was made as inclusion cyst, mullerian cyst, endometriosis, gartners duct cyst- rare posteriorly, ovarian cyst, enterocele. Patient was admitted and investigated. Routine blood investigations were within normal limits.

On ultrasonography $5 \times 4 \mathrm{~cm}$ cyst was seen in vagina with polypoidal mass of $1.7 \times 1.5 \mathrm{~cm}$ arising from cyst wall suggestive of complex vaginal cyst.

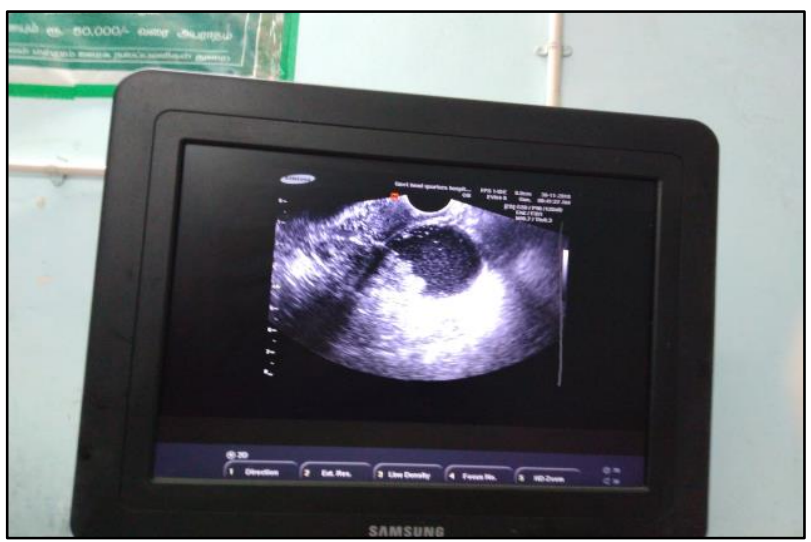

Figure 1: TVS USG suggestive of complex vaginal cyst.

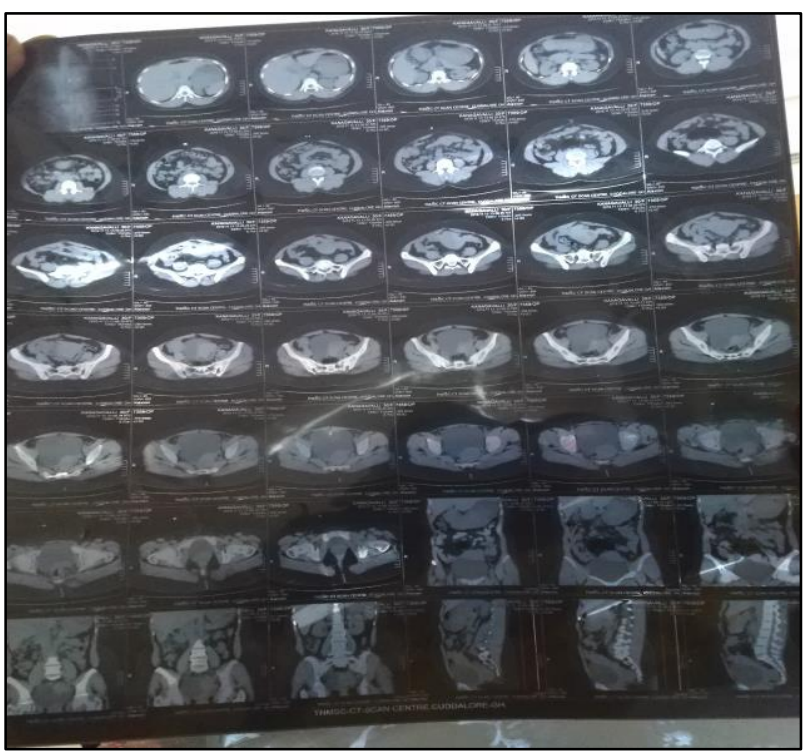

Figure 2: CT (A+P) PLAIN.

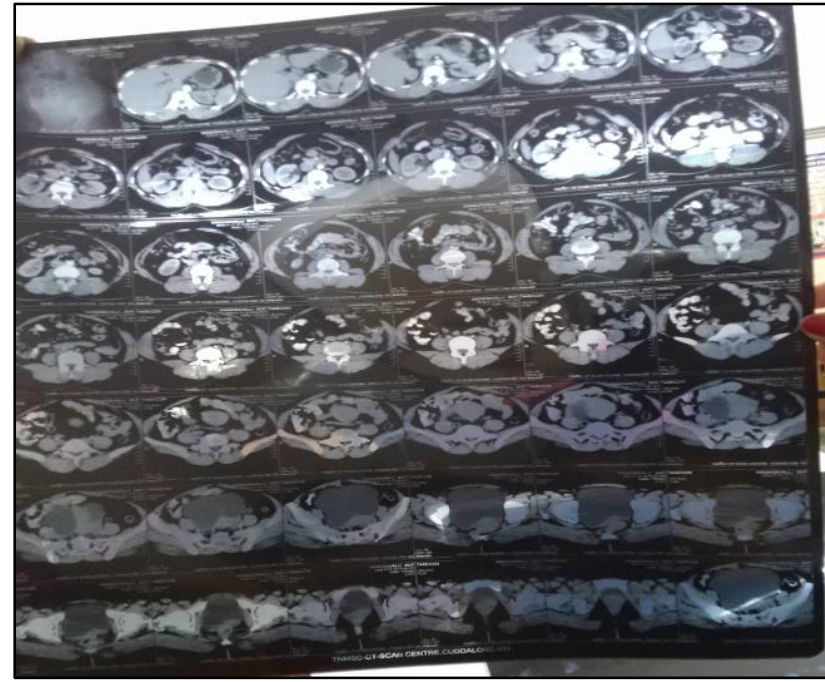

Figure 3: CT (A+P) Contrast posterior vaginal cyst of $6 \times 5 \mathrm{~cm}$.

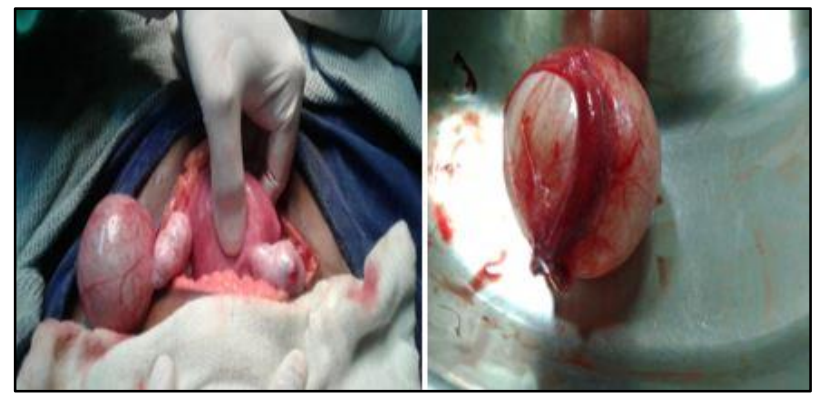

Figure 4: Gross examination of specimen.

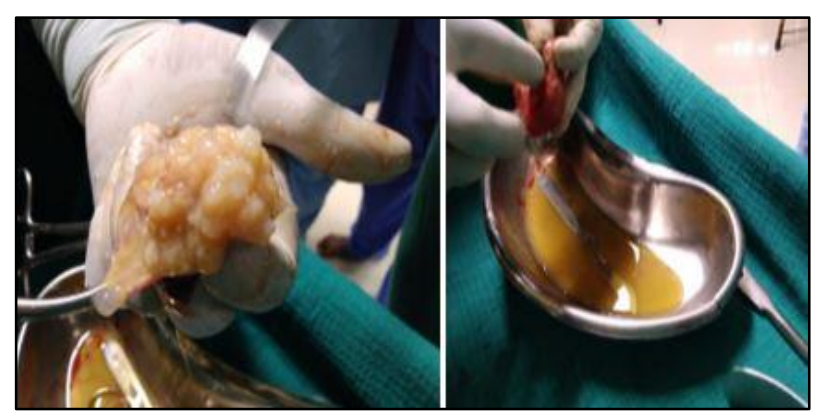

Figure 5: Cut section of specimen.

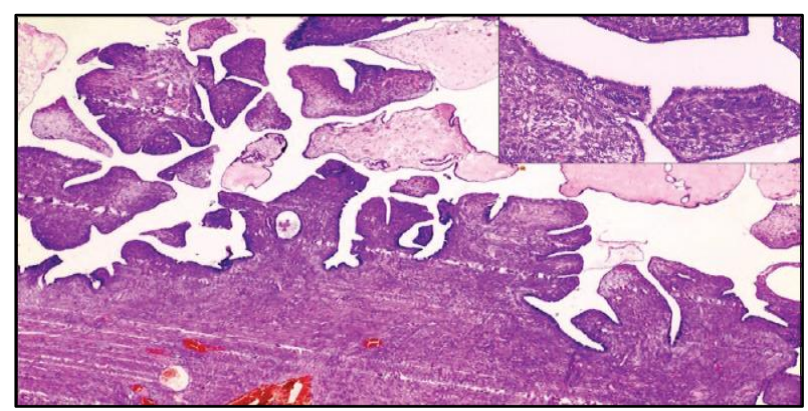

Figure 6: HPR of benign paillary cystadenofibroma of fallopian tube. 
Table 1: Reported cases of cystadenofibroma of fallopian tube.

\begin{tabular}{|c|c|c|c|c|c|c|}
\hline Authors & $\begin{array}{r}\text { Year of } \\
\text { publicatic }\end{array}$ & & $\begin{array}{c}\text { Age } \\
\text { (years) }\end{array}$ & gs treatment & Site and size & Microscopy \\
\hline $\begin{array}{l}\text { Kanbour et } \\
\mathbf{a l}^{3}\end{array}$ & 1973 & 63 & $\begin{array}{l}\text { Incidental finding dur } \\
\text { Vaginal hysterectomy }\end{array}$ & $\begin{array}{l}\text { surgery for } \\
\text { olapse }\end{array}$ & $\begin{array}{l}\text { Intramural part of } \\
\text { left uterine cornua, } \\
2 \mathrm{~cm}\end{array}$ & $\begin{array}{l}\text { Cystic papillary } \\
\text { adenofibroma }\end{array}$ \\
\hline $\begin{array}{l}\text { Silverman et } \\
\text { al }^{4}\end{array}$ & 1978 & 36 & $\begin{array}{l}\text { Incidental finding dur } \\
\text { Bilateral partial follov } \\
\text { pregnancy salphingec }\end{array}$ & $\begin{array}{l}\text { tubal ligation } \\
\text { g termination of } \\
\text { ny }\end{array}$ & $\begin{array}{l}\text { Cystic mass at } \\
\text { fimbrial end of left } \\
\text { tube, } 3.5 \mathrm{~cm}\end{array}$ & $\begin{array}{l}\text { Serous } \\
\text { cystadenofibroma }\end{array}$ \\
\hline de la Fuente ${ }^{5}$ & 1982 & 73 & $\begin{array}{l}\text { Incidental finding dur } \\
\text { TAH with BLSO uter }\end{array}$ & $\begin{array}{l}\text { ig surgery for } \\
\text { e leiomyomas }\end{array}$ & $\begin{array}{l}\text { Fimbrial end of } \\
\text { right fallopian tube, } \\
2.5 \times 2 \times 2 \mathrm{~cm}\end{array}$ & $\begin{array}{l}\text { Mixed mullerian } \\
\text { tumor- } \\
\text { adenofibroma }\end{array}$ \\
\hline $\begin{array}{l}\text { Casasola and } \\
\text { Mindan }^{6}\end{array}$ & 1989 & 32 & $\begin{array}{l}\text { Incidental finding } \\
\text { during operation for } \\
\text { multiple uterine } \\
\text { leiomyomas }\end{array}$ & $\begin{array}{l}\text { Hysterosalpingo- } \\
\text { opherectomy }\end{array}$ & NA & Cystadenofibroma \\
\hline Chen $^{7}$ & 1994 & 24 & Primary infertility & $\begin{array}{l}\text { BL tubal } \\
\text { cystectomy with } \\
\text { wedge biopsy of } \\
\text { the ovary }\end{array}$ & $\begin{array}{l}\text { Fimbrial end of } \\
\text { right and left } \\
\text { fallopian tube, } \\
2.5 \times 2 \mathrm{~cm} \text { and } \\
0.3 \times 0.2 \mathrm{~cm} \\
\text { respectively }\end{array}$ & $\begin{array}{l}\text { Bilateral papillary } \\
\text { adenofibroma }\end{array}$ \\
\hline Sills et al $^{8}$ & 2003 & NA & $\begin{array}{l}\text { Incidental finding } \\
\text { during IVF embryo } \\
\text { transfer }\end{array}$ & $\begin{array}{l}\text { Laparoscopic } \\
\text { tubal cystectomy }\end{array}$ & $\begin{array}{l}\text { Distal end of right } \\
\text { fallopian tube, } 5.5 \\
\mathrm{~cm}\end{array}$ & $\begin{array}{l}\text { Serous } \\
\text { cystadenofibroma }\end{array}$ \\
\hline $\begin{array}{l}\text { Gürbüz and } \\
\text { Ozkara }^{9}\end{array}$ & 2003 & 48 & $\begin{array}{l}\text { Irregular vaginal } \\
\text { bleeding with uterine } \\
\text { leiomyomas }\end{array}$ & TAH with BLSO & $\begin{array}{l}\text { Serousal surface of } \\
\text { right fallopian tube, } \\
0.4 \mathrm{~cm}\end{array}$ & $\begin{array}{l}\text { Serous } \\
\text { cystadenofibroma }\end{array}$ \\
\hline $\begin{array}{l}\text { de Silva et } \\
\text { al }^{10}\end{array}$ & 2010 & 19 & $\begin{array}{l}\text { Pain in right iliac } \\
\text { fossa }\end{array}$ & Right SO & $8 \mathrm{~cm}$ & Cystadenofibroma \\
\hline Mondal $^{11}$ & 2010 & 27 & Ectopic pregnancy & $\begin{array}{l}\text { Left } \\
\text { salpingectomy }\end{array}$ & $\begin{array}{l}\text { Fimbrial end of left } \\
\text { fallopian tube, } \\
2 \times 1.5 \mathrm{~cm}\end{array}$ & $\begin{array}{l}\text { Adenofibroma } \\
\text { with ectopic } \\
\text { pregnancy }\end{array}$ \\
\hline $\begin{array}{l}\text { Erra and } \\
\text { Costamagna }^{1} \\
\end{array}$ & 2012 & 50 & $\begin{array}{l}\text { Incidental finding } \\
\text { during operation for } \\
\text { leiomyomas }\end{array}$ & TAH with BLSO & Fimbrial cyst, $3 \mathrm{~cm}$ & $\begin{array}{l}\text { Serous } \\
\text { cystadenofibroma }\end{array}$ \\
\hline $\begin{array}{l}\text { Pandey et } \\
\text { al }^{13}\end{array}$ & 2012 & 20 & $\begin{array}{l}\text { Incidental finding dur } \\
\text { LSCS with BLTL LS }\end{array}$ & $\begin{array}{l}\text { g emergency } \\
\text { S with BLTL }\end{array}$ & $\begin{array}{l}\text { Cystic mass in the } \\
\text { fimbrial end of } \\
\text { left tube, } 4 \times 3 \mathrm{~cm}\end{array}$ & $\begin{array}{l}\text { Serous } \\
\text { cystadenofibroma }\end{array}$ \\
\hline $\begin{array}{l}\text { Fukushima } \\
\text { et al }\end{array}$ & 2014 & 32 & \multicolumn{3}{|c|}{$\begin{array}{l}\text { Incidental finding during operation for Linear salphingoostomy } \\
\text { Solid cystic mass near ampule a suspected case of ectopic } \\
\text { pregnancy and evisceration of left fallopian tube, } 20 \mathrm{~mm}\end{array}$} & $\begin{array}{l}\text { Papillary } \\
\text { cystadenofibroma }\end{array}$ \\
\hline $\begin{array}{l}\text { Yasmeen k et } \\
\text { al }^{1}\end{array}$ & 2015 & 30 & \multicolumn{3}{|c|}{$\begin{array}{l}\text { Incidental finding during operation for Left tubal cystectomy } \\
\text { Solid cystic mass on the a suspected case of ovarian neoplasm } \\
\text { serosal aspect of left fallopian tube, } 12 \times 10 \mathrm{~cm}\end{array}$} & $\begin{array}{l}\text { Serous papillary } \\
\text { cystadenofibroma }\end{array}$ \\
\hline
\end{tabular}

Computed tomography $(\mathrm{CT})$ scan $(\mathrm{A}+\mathrm{P})$ plain-posterior vaginal cyst of $6 \times 5 \mathrm{~cm}$ and on $\mathrm{CT}(\mathrm{A}+\mathrm{P})$ contrast scan cyst near posterior fornix with no enhancement after contrast of size $5.5 \times 4 \mathrm{~cm}$ s/o posterior vaginal cyst was seen. Decision of cyst removal was taken. In operation theatre under anaesthesia per vaginal and per rectal examination was done. $5 \times 6 \mathrm{~cm}$ mass was felt in posterior fornix but arising from left pelvis. Laparotomy was planned and Pfannesteil incision was taken. Intra operative uterus, right ovary, left ovary, right fallopian tube was normal. Same cystic mass of $5 \times 6 \times 7 \mathrm{~cm}$ was seen arising from serosal surface of left fallopian tube near fimbrial end. Left fimbrial cystectomy with salpingectomy was done.

Examination of specimen - gross examination - smooth wall cyst and on cut section- smooth cyst wall with papillary excrescences was seen. Specimen was sent for histopathological examination. Postoperative CA125-26 $\mathrm{U} / \mathrm{ml}$. 
HPR- Benign papillary cystadenofibroma of fallopian tube. Cyst wall was composed of fibrous and muscular walls of tube. Papillary folds enclosing solid fibrous stroma lined by single layer of tall columnar epithelium.

Postoperative period was uneventful. Suture removal was done on 7 th postoperative day. Wound was healthy. She has since been followed up in the out-patients clinic over a 12 months period and was found to do well with no evidence of recurrence of disease.

\section{DISCUSSION}

Adenofibromas are relatively rare benign tumors arising from the germinal lining and ovarian stroma with rare malignant potential. Of all the reported adenofibromas majority are of serous type. However, endometrioid, mucinous and clear cell types also exist. Table 1 shows a systematic review of the cases of cystadenofibromas arising from the fallopian tube. ${ }^{2}$

It presents as solitary round mass arising from intraluminal or serosal surface of fimbrial end. Usual age of presentation is 4 th to 5 th decades. Our case was 30 years a rare presentation. Tumor presents with symptoms of abdominal pain, palapable mass, vaginal bleeding, urinary or bowel complaints. Differential diagnosis of tumors of tubal origin includes tubal carcinoma (primary/metastatic, serous tumor of low malignant potential (STLMP), borderline papillary serous tumor.

Histologically similar to ovarian tumor but differs in topogrphic localisation.

Finding of Mullerian type epithelium, immunephenotypic profiles of vimentin, cytokeratin co expression and diffuse apical epithelial membrane antigen immunoreactivity suggestive of tumor origin from embryonic remnant from Mullerian duct.

\section{CONCLUSION}

Benign serous papillary cystadenofibroma of fallopian tube tumor is rare and dignosed incidentally. It should be differentiated from other fallopian tube tumors as prognosis and management differs. It is having rare malignant potential. It usually presents in young women with impact on fertility. So cystectomy is the only treatment required. So, decision for radical surgery should be reconsidered. This case is presented on account of its rarity and we believe this is the first reported case of benign serous papillary cystadenofibroma of the fallopian tube to present as posterior fornix cyst.

Funding: No funding sources

Conflict of interest: None declared

Ethical approval: Not required

\section{REFERENCES}

1. Khatib Y, Patel RD, Kashikar AS, Chavan K. Serous papillary cystadenofibroma of the fallopian tube: A case report and short review of literature. Indian $\mathbf{J}$ Pathol Microbiol. 2015;58(4):524-7.

2. Hodzic E, Pusina S, Bajramagic S, Salibasic M, Holjan S. Papillary Cystadenofibroma of Fallopian Tube: Case Report with a Literature Review. Med Arch. 2020;74(1):73-6.

3. Kanbour AI, Burgess F, Salazar H. Intramural adenofibroma of the fallopian tube. Light and electron microscopy. Cancer. 1973;31:1433-9.

4. Silverman AY, Artinian B, Sabin M. Serous cystadenofibroma of the fallopian tube: A case report. Am J Obstet Gynecol. 1978;130:593-5.

5. de la Fuente AA. Benign mixed Müllerian tumour Adenofibroma of the fallopian tube. Histopathology. 1982;6:661-6.

6. Valerdiz Casasola S, Pardo Mindan J. Cystadenofibroma of fallopian tube. Appl Pathol. 1989;7:256-9.

7. Chen KT. Bilateral papillary adenofibroma of the fallopian tube. Am J Clin Pathol. 1981;75:229-31.

8. Sills ES, Kaplan CR, Perloe M, Tucker MJ. Laparoscopic approach to an uncommon adnexal neoplasm associated with infertility: Serous cystadenofibroma of the fallopian tube. J Am Assoc Gynecol Laparosc. 2003;10:545-7.

9. Gürbüz Y, Ozkara SK. Immunohistochemical profile of serous papillary cystadenofibroma of the fallopian tube: A clue of paramesonephritic origin. Appl Immunohistochem Mol Morphol. 2003;11:153-5.

10. de Silva TS, Patil A, Lawrence RN. Acute presentation of a benign cystadenofibroma Mondal SK. Adenofibroma and ectopic pregnancy of left fallopian tube: A rare coexistence. J Obstet Gynaecol Res. 2010;36:690-2.

11. Erra S, Costamagna D. Serous cystadenofibroma of the fallopian tube: Case report and literature review. G Chir. 2012;33:31-3.

12. Pandey A, Nandini NM, Sarkar A, Tangri R, Bhattacharya S. Benign cystadenofibroma of the fallopian tube: A case report. J Physiol Pathophysiol. 2012;3:29-30.

13. Fukushima A, Shoji T, Tanaka S, Sugiyama T. A case of fallopian tube adenofibroma: Difficulties associated with differentiation from ectopic pregnancy. Clin Med Insights Case Rep. 2014;7:1357.13-21.

Cite this article as: Narayanrao GP, Srinivasan PV, Kala R. Benign papillary cystadenofibroma of fallopian tube presenting as posterior fornix cyst: case report. Int J Reprod Contracept Obstet Gynecol 2021;10:364-7. 